\title{
低出力レーザーおよび直線偏光近赤外線直接照射の 皮虐微小循環に対する効果
}

\author{
小森 万希子 \\ 東京女子医科大学東医療センター麻酔科 \\ (受付: 平成 20 年 1 月 29 日, 受理 : 平成 20 年 2 月 24 日)
}

\section{Effects of Irradition Therapy by Low-power Laser or Linearly-polarized Near-infrared Light on the Skin Microcirculation}

\author{
Makiko KOMORI \\ Department of Anesthesiology, Medical Center East, Tokyo Women’s Medical University
}

(Received: January 29, 2008, Accepted for Publication: February 24, 2008)

\begin{abstract}
Treatment regimens used in pain clinics include oral drugs, nerve blocks, and physical therapy. Recently, phototherapy, a noninvasive treatment with minimal side effects, has been used for pain management in elderly patients in whom nerve blocks cannot be performed because of concurrent disease. We used the rabbit ear chamber method under direct vision to examine changes in the arteriolar microcirculation after phototherapy. Low-power laser light (laser group) and linearly polarized near-infrared light (near-infrared group) were used to measure the luminal diameter, blood-flow velocity, and blood volume of the arterioles. As compared with the values before treatment (100\%), the arteriolar diameter increased to $101.9 \% \pm$ $5.9 \%$ in the control group, $130.1 \% \pm 10.4 \%$ in the laser group, and $125.2 \% \pm 16.9 \%$ in the near-infrared group. These increases in both the laser and near-infrared groups were significant as compared with the control value $(\mathrm{p}<0.05)$. Blood-flow velocity increased from a baseline value of $100 \%$ to $101.3 \% \pm 3.6 \%$ in the control group, $126.3 \% \pm 14.8 \%$ in the laser group, and $129.1 \% \pm$ $16.8 \%$ in the near-infrared group. The increases in both the laser and near-infrared groups were significant as compared with that in the control group $(\mathrm{p}<0.05)$. Arteriolar blood volume showed a similar trend, and significantly increased after phototherapy $(\mathrm{p}<0.05)$. Phototherapy improved the microcirculation with minimal systemic and local side effects and can therefore be used as adjuvant therapy. Laser therapy is very often used in the field of pain management. Laser therapy alone or combined with other treatments such as nerve blocks and drug therapy has been shown to be effective. Previous basic research, including our study, has suggested that the mechanism by which laser therapy relieves pain involves factors such as the selective inhibition of peripheral-nerve conduction, relaxation of vascular smooth muscle, and arteriolar dilation due to the inhibition of sympathetic-nerve activity. In addition to relieving pain, laser therapy can reduce inflammation and promote wound healing. We describe our findings and the clinical usefulness of laser therapy in the field of pain management.
\end{abstract}

(J. Jpn. Soc. Laser Dent. $19: 26 \sim 29,2008$ Reprint requests to Dr. KOMORI)

Key words = Linearly-polarized Near-infrared Light, Low-power laser, Microcirculation, Pain clinic

キーワード＝直線偏光近赤外線, 低出カレーザー, 微小循環, ペインクリニック

\section{緒言}

痛みの治療は内服薬, 神経ブロック, 経皮的神経刺激, 温浴, 低周波, 超音波, 近赤外線, 精神分析, 電極埋め込 み，手術療法など多彩であり，患者に合った治療を提供
できることが必要である。最近の高齢化に伴い, 合併症を 持つ患者に神経ブロックなどができない場合, 非侵襲で副 作用が少なく，即効性のある治療が望まれ，さらに衰えた 生体機能や細胞の賦活する治療へと要求が高まっている。 これらの要求に期待されているのがレーザー治療である。

干 116-8567 東京都荒川区西尾久 2-1-10 TEL 03-3810-1111 FAX 03-3800-7873

2-1-10 Nishiogu, Arakawa-ku, Tokyo 116-8567, Japan. TEL +81-3-3810-1111 FAX + 81-3-3800-7873 
またレーザー照射で創傷治癒が促進することも研究されて いる。

光線療法の効果のひとつとして, 鎮痛作用に加えて微小 循環改善作用がこれまで報告されている1) が，直接末梢血 管の変化をみた報告は少なく, 定量性と客観性にそしいと いわれている。我々はレーザー照射による細動脈の血流の 変化をウサギ耳透明空 (Rabbi Ear Chamber：REC) 法 ${ }^{2)}$ を用いて直視下に観察した。REC 法は同一血管の径と赤 血球の移動速度を生体顕微鏡的に観察することが可能な方 法である。このためいろいろな刺激や薬物投与に扔ける血 管径の反応を連続してリアルタイムに観察できる。これま で，我々は REC 法を用いて各種ショックモデル ${ }^{3.4)}$ ，吸入 酸素濃度の変化 ${ }^{5}$, 動脈血二酸化炭素濃度の変化 ${ }^{6)}$ におけ る微小循環の研究, そして創傷治瘉における血管新生の過 程を血管成長因子である塩基性線維芽細胞増殖因子 (basic fibroblast growth factor；bFGF）を用いて研究 7)してき た。今回は低出力レーザー照射抢よび直線偏光近赤外線照 射の効果を検討したので，この研究成果拈よびペインクリ ニックでのレーザー照射の臨床応用について報告する。

\section{実験方法}

本研究は東京女子医科大学倫理委員会で承認を得た。耳 介に浅野ら ${ }^{2)}$ の方法によりアクリル樹脂製耳透明空 (rabbit ear chamber，以下 REC）を装着した体重 3-4kg の日本白 色種ウサギの雄 27 羽を用いて, REC 装着 6 週間後に REC に再生された微小血管の循環動態を観察した。RECを生 体顥微鏡下に固定して，1/10,000 秒のシャッター速度の顕 微鏡用ビデオカメラ（ソニーDXC750，東京）で記録，観 察した。ウサギにペントバルビタール $30 \mathrm{mg} / \mathrm{kg}$ を静注後, 気管内抻管をし，自発呼吸で維持した。対象を無作為に低 出力レーザー照射群 (レーザー群, $\mathrm{n}=9$ ), 直線偏光近赤 外線照射群（近赤外線群， $\mathrm{n}=9$ ） と擬似照射群（対照群, $\mathrm{n}=9$ ）に分けた。レーザー群の出力器は低出力ガリウムアルミニウム- 砒素半導体レーザー装置（FLAT10 日本 赤外線工業，東京）を用いた。波長は $830 \mathrm{~nm}$, 出力は最高 $100 \mathrm{~mW}$ で接触型レーザーであり，プローブが皮膚に接触 中に照射が行われる。近赤外線群は直線偏光近赤外線機器 (Super Lizer HA-30, 東京医研究社, 東京) を使用した。 この照射器はスーパーアイオダインランプを光源として, 光学フィルターを介して短波長成分の近赤外線（600～ 1,600nm）のみを取り出して照射する。近赤外線は通常赤 外線（遠赤外線を含む）の中でも生体深達度が高い。光源 が赤外線灯であるので $1,800 \mathrm{~mW}$ と高エネルギーを供給で きる特徵を有する。対照群はSuper Lizer と同じ外見の擬 似装置で接触型プローブを用いた。対照として擬似装置を 用いた理由は，接触するレンズユニットの形態から触圧刺 激も関与する可能性がある。触圧の物理刺激によって末梢
循環に変動をきたすこともあり得るので，今回，光線療法 の末梢循環に与える影響を評価するため擬似装置を用い た。レーザー群は $60 \mathrm{~mW}$ 照射し，近赤外線群は $1,540 \mathrm{~mW}$

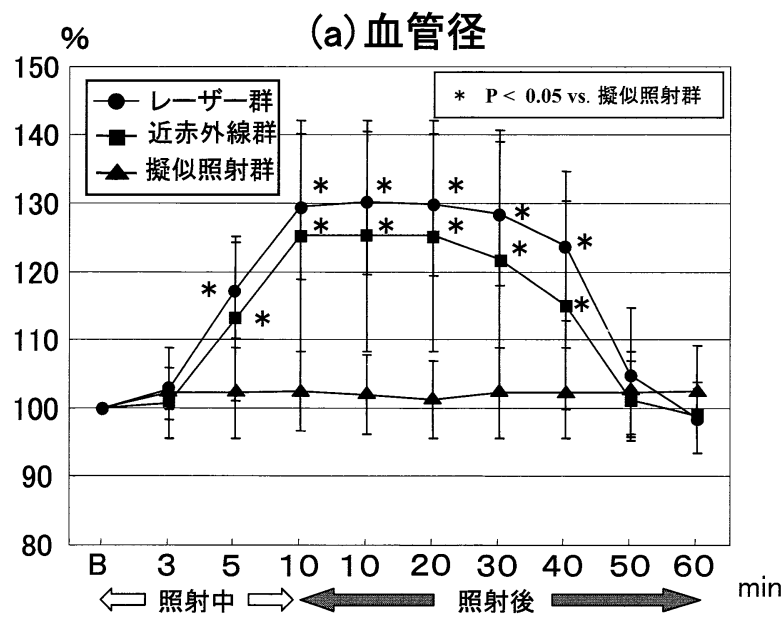

(b) 血流速度

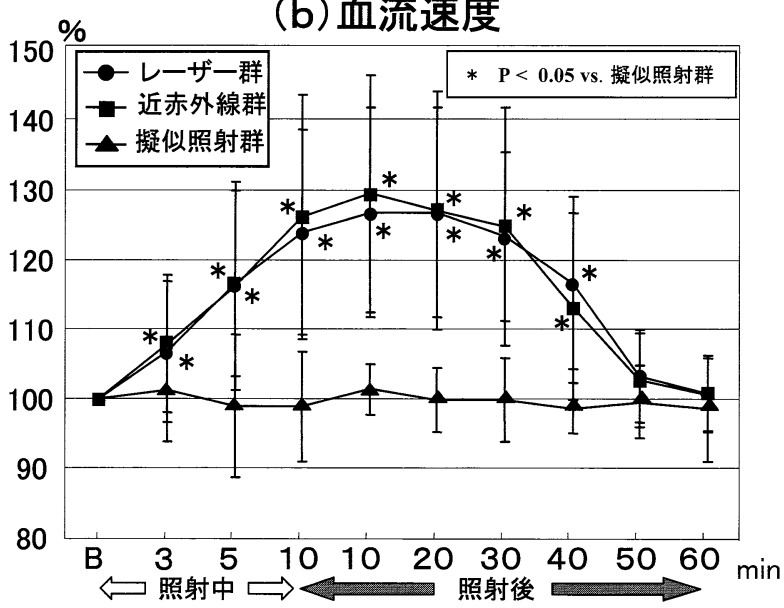

(c) 血流量

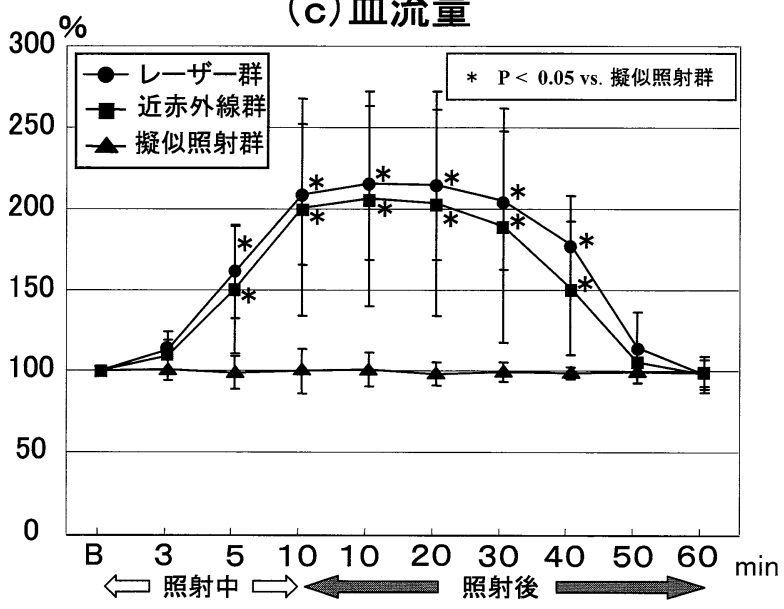

図 1 細動脈の血管径, 血流速度, 血流量の变化率 $\mathrm{B}$ : base line（照射前） 


\section{レーザー照射例}

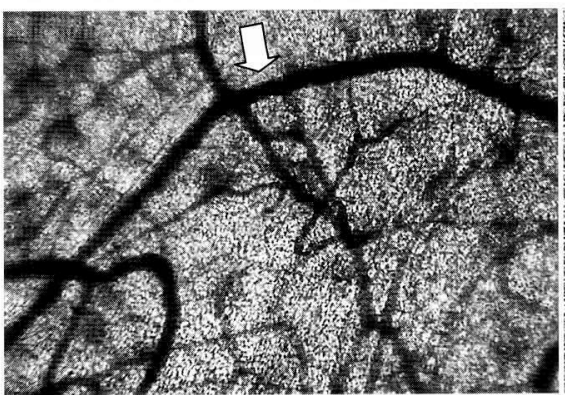

照射前

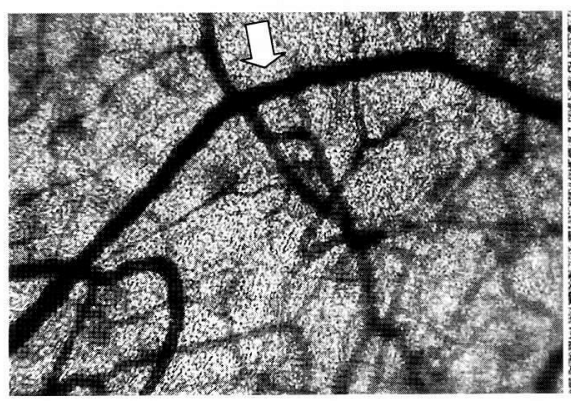

照射10分後
近赤外線照射例

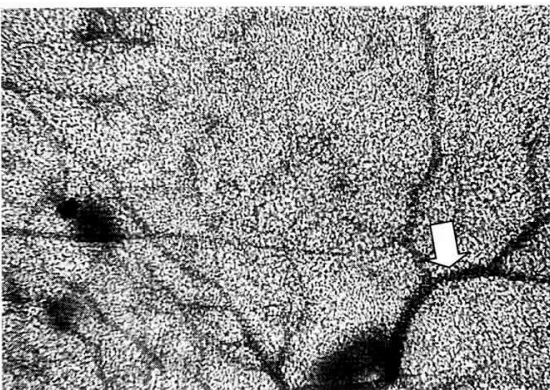

照射前
擬似照射例

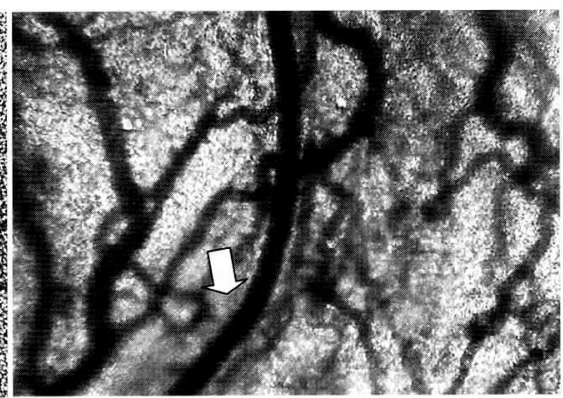

照射前

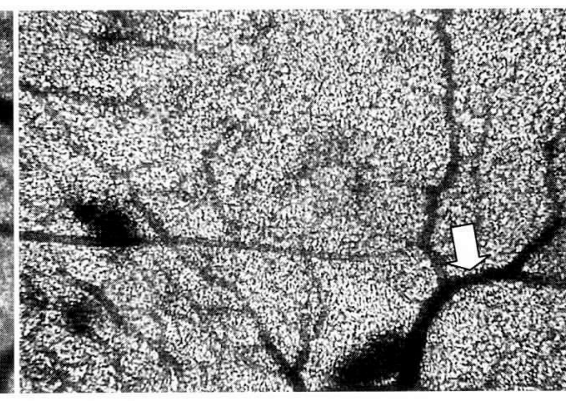

照射10分後

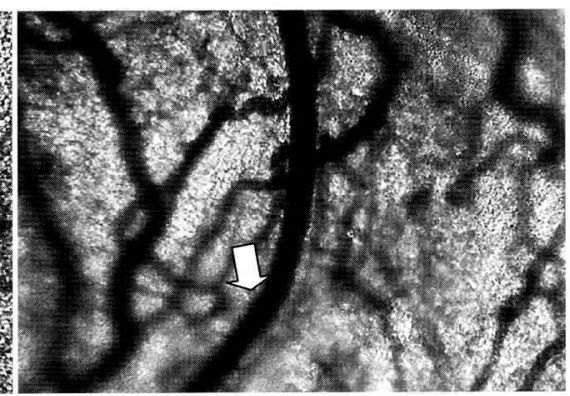

照射10分後

図 2 観察した微小循環の例

矢印は細動脈。レーザー照射例と近赤外線照射例では細動脈の拡張がみられる。 擬似照射例では変化はみられていない。

で 1 秒照射，4秒停止を繰り返した。3 群とも接触型プ ローブを使用して REC 支配領域の動脈の根部に 10 分間 照射した。照射前から処置後 60 分にわたり細動脈の血管 径と血流速度を测定した。血流速度はビデオカメラの画 面を $1 / 60$ 秒の速度で再生し，赤血球の移動距離を 10 点 測定して平均值を求めた。血流量は血流速度と血管の断 面積の積より算出した。有意差検定は, Student $t$-test およ び ANOVA 検定を用い有意水準は 5\%以下とした。

\section{結果}

細動脈の血管径，血流速度および血流量の変化率を眓 1 に示した。細動脈の血管径は照射前を $100 \%$ とすると照射 10 分後, 詨照群では $101.9 \pm 5.9 \%$ に対して, レーザー群 は $130.1 \pm 10.4 \%$ に，近赤外線群では $125.2 \pm 16.9 \%$ とな り，対照群に比べ有意に上昇した（p<0.05）。血流速度は 照射前を $100 \%$ とすると照射 10 分後, 対照群では $101.3 \pm$ $3.6 \%$ に対して，レーザー群は $126.3 \pm 14.8 \%$ に，近赤外線 群では $129.1 \pm 16.8 \%$ となり，対照群に比べ有意に上昇し た $(p<0.05)$ 。血流量は照射前を $100 \%$ とすると照射 10 分後, 対照群では $101.2 \pm 10.5 \%$ に対して, レーザー群で は $215.8 \pm 47.7 \%$ に，近赤外線群では $206.2 \pm 66.3 \%$ と
なり，対照群に比べ有意に上昇した（ $\mathrm{p}<0.05 ）$ 。近赤外 線群とレーザー群では有意差は認めなかった。観察した微 小循環の例を図 2 に示した。近赤外線照射例とレーザー照 射例では照射後に細動脈の拡張がみられ，擬似照射例では 変化がみられなかった。

\section{考察}

これまでのレーザー治療による末梢血流の変化をみた例 は，Banzer ら ${ }^{8)}$ はレーザ針の刺激が末梢の組織酸素化の 変化はないが，微小循環を改良することを示した。

Ihsan $^{9)}$ はウサギの大腿動脈結䅨モデルで, 低出力レー ザー治療により, 組織病理学検査において毛細血管直径が 増加し, 線維芽細胞増殖因子 (FGF) の上昇を認めたと 報告している。これらの報告はレーザー治療が血流を改善 させる間接証明であるが, 我々の研究は直視下で観察した 直接証明である。

Maegawa ら ${ }^{1)}$ はラットの腸間膜を用いてレーザー照射 が微小循環に及ぼす影響について検討した。 $80 \%$ の血流増 加の主な機序として血管平滑筋細胞膜の $\mathrm{Ca}^{2+}$ に影響を与 え, 細胞内 $\mathrm{Ca}^{2+}$ イオンが低下して平滑筋が弛緩すると報 告している。さらに血管反応における一酸化窒素 (nitric 
oxide；NO）の関与を調べる目的でNO 合成阻害薬の L-NAME 投与下にレーザー照射を行うと, 細動脈径の拡 張は認められず，NO がレーザー照射による血流増加の一 因になっていることが示唆された。

$$
\text { レーザー照射は, ペインクリニック領域では非常によく }
$$

用いられている治療手段である。神経ブロック療法や薬物 療法などの治療法との併用あるいは適切な単独使用により 良い効果が得られている。我々の研究も含めてこれまでの 基礎的研究からレーザー治療による鎮痛作用の機序とし て，末梢神経の選択的興奮伝導抑制，血管に対しては血管 平滑筋弛緩，交感神経抑制による細動脈の拡張などが考え

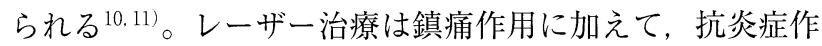
用や創傷治癒促進作用がある ${ }^{12)}$ 。

ペインクリニックで用いる光線療法の対象疾患は, まず 鎮痛，抗炎症作用としては関節痛（慢性関節リウマチ，変 形性膝関節症, 変形性股関節症), 炎症痛 (腱鞘炎, 肩関 節周囲炎, 时関節炎, 頸椎捻挫), 神経痛 (三叉神経痛, 坐骨神経痛, 後頭神経痛, 带状疱疹後神経痛, 肋間神経 痛, 腰痛症など), 筋肉痛, 術後疼痛などがある。血流障 害として，上肢，下肢の血流障害（閉塞性血栓血管炎，閉 塞性動脈硬化症), 創傷治瘉促進作用としては創傷, 手術 創, 裖瘡, 難治性潰瘍などに用いられる。また, レーザー による星状神経節近傍照射 ${ }^{13)} も$ 臨床的にはよく行われて いる。星状神経節ブロックの適応としては頭部, 顔面, 頸 部, 上肢および前胸部の有痛性疾患, 顔面神経麻痺, 顔面 㽷攣，突発性難聴，鼻アレルギー，網膜血管閉塞症などの 無痛性疾患がある。星状神経節ブロックの合併症として全 身㽷攣（椎骨動脈への誤注入）, 嗄声, 嚥下困難, 上肢の 麻痺, 血腫（総頸動脈穿刺）がある。星状神経節近傍照射 の特徴と適応は, 手技が容易, 合併症がない, 薬物アレル ギーがない，恐怖心がないなどである。星状神経節近傍照 射の適応は星状神経節ブロックの適応と同じだが，特に高 歯会, 年少者, 抗凝固療法中の患者でよい適応である。

\section{結 論}

ウサギ耳介の透明空法を用いて, 細動脈の血流の変化を 直視下に観察し, 低出力レーザーおよび直線偏光近赤外線 直接照射の効果を検討した。光線照射により細動脈の血管 径, 血流速度, 血流量は上昇した。光線療法の臨床使用で 疼痛, 浮腫の軽減や関節の可動域の増大などに効果があ る。本実験結果から，血管拡張による循環の促進により，
酸素供給の増加，発痛物質の除去をもたらし，鎮痛，筋緊 張の緩和などが起こることが推測される。

本稿は，第 19 回日本レーザー歯学会総会（平成 19 年 11 月 24 日，横浜シンポジウム）において発表した内容の一部をまとめた ものである。

また, 本研究の一部は平成 18,19 年度文部科学省科学研究補助 金（基盤研究 C：課題番号 18591727）によって行われた。

\section{文献}

1) Maegawa $Y$, Itoh $T$, Hosokawa $T$, et al: Effects of nearinfrared low-level laser irradiation on microcirculation. Lasers Surg Med, 27 : 427-437, 2000.

2) Asano M, Ohkubo C: Physiological and pathophysiological events of cutaneous microcirculation observed in the rabbit ear chamber. In: Intravital Observation of Organ Microcirculation. Tsuchiya M, Wayland H, Oda M, Ozaki I (eds). Amsterdam-Oxford-Princeton, 1983, Excerpta Medica, 31-48.

3) Komori M, Takada K, Tomizawa $Y$, et al: Urinary trypsin inhibitor improves peripheral microcirculation and bronchospasm associated with systemic anaphylaxis in rabbits in vivo. Shock, $20: 189-194,2003$.

4) Komori M, Takada K, Tomizawa Y, et al: Effects of colloid resuscitation on peripheral microcirculation, hemodynamics, and colloidal osmotic pressure during acute severe hemorrhage in rabbits. Shock, $23: 377-382,2005$.

5) Komori M, Takada K, Ozaki M: Effects of inspired oxygen concentration on peripheral microcirculation studied by the rabbit ear chamber method. in vivo, $15: 303-308,2001$.

6) Komori M, Takada K, Tomizawa $Y$, et al: Permissive range of hypercapnia for improved peripheral microcirculation and cardiac output in rabbits. Crit Care Med, $35: 2171-$ 2175, 2007.

7) Komori M, Tomizawa Y, Takada K, et al: A single local application of recombinant human basic fibroblast growth factor accelerates initial angiogenesis during wound healing in rabbit ear chamber. Anesth Analg, $100: 830-834,2005$.

8) Banzer W, Hübscher M, Seib M, et al: Short-time effects of laser needle stimulation on the peripheral microcirculation assessed by laser Doppler spectroscopy and near-infrared spectroscopy. Photomed Laser Surg, $24: 575-580,2006$.

9) Ihsan FR: Low-level laser therapy accelerates collateral circulation and enhances microcirculation. Photomed Laser Surg, $23: 289-294,2005$.

10）細川豊史：低反応レベルレーザー，ペインクリニック，26： 662-670, 2005

11）佐伯 茂, 朝野宏子, 針谷 伸：低反応レベルレーザーによ る痛み治療。ペインクリニック， 26：791-801， 2005.

12）眞㴊 敏：低出カレーザー療法. 理学療法学, $32: 262-264$, 2005.

13）吉田憲司：口腔領域における神経疾患への低出力レーザー治 療. 日レ医会誌, $28: 77-83,2007$. 